\title{
Comparison of clinical outcomes following CuT-380A insertion in postplacental period with interval insertion
}

\author{
Divya Chauhan, Shalini Gainder*
}

Department of Obstetrics and Gynecology, Postgraduate Institute of Medical Education and Research, Chandigarh, India

Received: 15 July 2017

Accepted: 08 August 2017

\section{*Correspondence:}

Dr. Shalini Gainder,

E-mail: shalinigainder@gmail.com

Copyright: (c) the author(s), publisher and licensee Medip Academy. This is an open-access article distributed under the terms of the Creative Commons Attribution Non-Commercial License, which permits unrestricted non-commercial use, distribution, and reproduction in any medium, provided the original work is properly cited.

\begin{abstract}
Background: Postplacental intra-uterine device has many benefits like providing contraception immediately after childbirth, non-interference with lactation and high efficacy. However, concerns about its safety have led to decreased use of this method of contraception. Hence, this study aims to compare the complication rates following insertion of immediate postplacental IUCD (PPIUCD) with interval insertion.

Methods: This is a prospective study conducted under the Department of Obstetrics and Gynaecology in PGIMER, Chandigarh. 196 women were included in the study. Women were divided in two groups, those who were inserted with immediate postplacental IUCD versus those who had IUCD insertion in interval period. The two groups were followed up for a period of 6 months and complications were recorded. The PPIUCD group was further subdivided into 2 subgroups based on mode of delivery, vaginal delivery and caesarean section. These PPIUCD subgroups were also compared.

Results: There was no statistically significant difference in the incidence of pelvic pain, infection, abnormal uterine bleeding and expulsion between the PPIUCD and interval group. However, when the PPIUCD subgroups were compared, it was seen that no woman in caesarean section subgroup had expulsion of IUCD whereas $9.8 \%$ women had expulsion in the vaginal delivery PPIUCD subgroup.

Conclusions: Postplacental and interval IUCD seem to be comparable for the incidence of various complications. However, intra-caesarean PPIUCD insertion seems to have a much lower expulsion rate as compared to vaginal delivery PPIUCD insertion.
\end{abstract}

Keywords: Complications, Interval, IUCD, Postplacental

\section{INTRODUCTION}

The unmet need for contraception is well known worldwide. Unwanted pregnancy has various adverse effects on the health of women. It also leads to depression and makes the women resort to unsafe abortions which increase maternal morbidity and mortality. Effective contraception has many social and economic benefits, besides just birth control. The method and timing of contraceptive measure is very important. Women are highly motivated to use contraception during the postpartum period. ${ }^{1}$ Among the various options available, IUCDs have various advantages over other methods which make them ideal for use as immediate post-partum contraceptive measure. They do not interfere with lactation, unlike hormonal methods. ${ }^{2}$ Postplacental IUCD provides contraception with immediate effect after child birth. Postplacental IUCD insertion can also be done during Caesarean section with minimal discomfort to the woman. This study aimed to compare the complication rates of postplacental with interval IUCD insertion. IUCD was inserted both following vaginal delivery and during 
caesarean section and the women were followed up for complications.

\section{METHODS}

This is a prospective study conducted under the Department of Obstetrics and Gynaecology in PGIMER, Chandigarh. The study was conducted for a period of one and a half years from July 2014 to Dec 2015.

The study included women between 18 and 45 years of age who delivered in PGIMER vaginally or by caesarean section and who consented for the study. Those women were excluded from the study who had contraindications to IUCD insertion like history of a sexually transmitted infection during the index pregnancy or in the last 3 months prior to enrolment, undiagnosed vaginal bleeding, recent (within last 3 months) or active intrauterine infection, known abnormal uterine cavity, any known cervical or uterine pathology or any known medical disorder. Also, women with contra-indications to PPIUCD such as intrapartum fever, postpartum hemorrhage, rupture of membranes for greater than $18 \mathrm{~h}$ prior to delivery and chorioamnionitis were excluded from the study. Women were divided into two groups. Group 1 included those women in whom IUCD was inserted within 10 minutes after placental delivery. Group 2 included those in whom IUCD was inserted in the interval period. Women found suitable for IUCD insertion were counselled right from antenatal period and further counselled at the time of admission to labour room. Women who consented were included in group 1. Total number of women counselled and the ones who did not agree for this method of contraception were also recorded to calculate the acceptance of this contraceptive method. Women in both the groups underwent $\mathrm{Cu} \mathrm{T}$ 380A IUCD insertion using standardized techniques (no touch technique for interval IUCD and Kelly's forceps for post-placental IUCD insertion). Women were followed up for 6 months and complications were noted.

\section{RESULTS}

196 women were included in the study, with 98 women in each of group 1 and 2 . In group 1, only 91 women could be followed up. Both the groups were followed up for a period of 6 months. Total 695 women were counselled for postplacental IUCD insertion.

Out of which 98 women agreed. Thus only $14.1 \%$ of the women agreed for postplacental IUCD insertion out of all the eligible women. The two groups were compared for the incidence of perforation, partial expulsion, complete expulsion, excessive bleeding, intermenstrual bleeding, pelvic infection and pelvic pain.

\section{Pelvic pain}

All the women in the interval group and the women in the postplacental group who underwent vaginal delivery were asked if they experienced any lower abdominal or pelvic pain on follow-up and the intensity was recorded on Visual Analog Scale (VAS). Mean pain scores on VAS were calculated in each group and were compared. There was no statistically significant difference in mean pain score between the two groups $(\mathrm{p}=0.739)$ (Table 1$)$.

Table 1: Pelvic pain in PPIUCD vaginal delivery group and interval IUCD group.

\begin{tabular}{|c|c|c|c|}
\hline Group & $\begin{array}{l}\text { Number } \\
\text { of women }\end{array}$ & $\begin{array}{l}\text { Mean } \\
\text { pain score }\end{array}$ & $\begin{array}{l}\mathbf{P} \\
\text { value }\end{array}$ \\
\hline $\begin{array}{l}\text { Postplacental } \\
\text { IUCD who } \\
\text { underwent } \\
\text { vaginal delivery }\end{array}$ & 41 & $0.17 \pm 0.704$ & \multirow[t]{2}{*}{0.739} \\
\hline Interval IUCD & 98 & $0.22 \pm 0.925$ & \\
\hline
\end{tabular}

\section{Perforation}

There were no cases of uterine perforation in either group.

\section{Expulsion}

In post placental group, $4.4 \%$ of the women had expulsion of the IUCD whereas in the interval group, $4.1 \%$ of the women had expulsion. This difference was not statistically significant (Table 2).

Table 2: Expulsion (partial and complete) in PPIUCD group and interval group.

\begin{tabular}{|lllll|}
\hline Group & $\begin{array}{l}\text { IUCD } \\
\text { expelled }\end{array}$ & $\begin{array}{l}\text { IUCD not } \\
\text { expelled }\end{array}$ & Total & P \\
\hline $\begin{array}{l}\text { Postplacental } \\
\text { IUCD }\end{array}$ & $4(4.4 \%)$ & $87(95.6 \%)$ & $91(100 \%)$ & value \\
\hline $\begin{array}{l}\text { Interval } \\
\text { IUCD }\end{array}$ & $4(4.1 \%)$ & $94(95.9 \%)$ & $98(100 \%)$ & 1.000 \\
\hline
\end{tabular}

\section{Abnormal uterine bleeding}

The number of women who had abnormal uterine bleeding were also comparable in the two groups as shown in the table below (Table 3).

Table 3: Abnormal uterine bleeding in PPIUCD group and interval group.

\begin{tabular}{|c|c|c|c|c|}
\hline Group & $\begin{array}{l}\text { Number } \\
\text { of women } \\
(\%) \\
\text { having } \\
\text { abnormal } \\
\text { uterine } \\
\text { bleeding }\end{array}$ & $\begin{array}{l}\text { Number } \\
\text { of women } \\
(\%) \text { not } \\
\text { having } \\
\text { abnormal } \\
\text { uterine } \\
\text { bleeding }\end{array}$ & Total & $\begin{array}{l}P \\
\text { value }\end{array}$ \\
\hline $\begin{array}{l}\text { Postplacental } \\
\text { IUCD }\end{array}$ & $12(13.2 \%)$ & $79(86.8 \%)$ & $91(100 \%)$ & \multirow{2}{*}{1.000} \\
\hline $\begin{array}{l}\text { Interval } \\
\text { IUCD }\end{array}$ & $13(13.3 \%)$ & $85(86.7 \%)$ & $98(100 \%)$ & \\
\hline
\end{tabular}




\section{Pelvic infection}

During the follow-up of 6 months, $4.4 \%$ of women had pelvic infection in postplacental IUCD group and $5.1 \%$ of women had pelvic infection in the interval group. But the difference was statistically insignificant (Table 4).

Table 4: Pelvic infection in PPIUCD group and interval group.

\begin{tabular}{|llll|} 
& $\begin{array}{l}\text { Postplacental } \\
\text { IUCD }\end{array}$ & $\begin{array}{l}\text { Interval } \\
\text { IUCD }\end{array}$ & $\begin{array}{l}\text { P } \\
\text { value }\end{array}$ \\
$\begin{array}{llll}\text { Number of } \\
\text { women having } \\
\text { pelvic infection }\end{array}$ & $4 / 91$ & $5 / 98$ & 1.000 \\
\hline
\end{tabular}

The postplacental IUCD group was further divided into 2 subgroups based on mode of delivery. Among the 91 women who followed up after postplacental IUCD insertion, 41 underwent IUCD insertion following vaginal delivery and 50 underwent intra-caesarean IUCD insertion. These postplacental IUCD subgroups were compared for expulsion rates, pelvic infection and abnormal uterine bleeding.

Only $7.3 \%$ women had abnormal uterine bleeding in the vaginal delivery subgroup as compared to $18 \%$ women in caesarean section subgroup. However, this difference was not statistically significant (Table 5).

Table 5: Abnormal uterine bleeding in PPIUCD subgroups.

\begin{tabular}{|lllll|}
$\begin{array}{l}\text { Postplacental } \\
\text { IUCD }\end{array}$ & $\begin{array}{l}\text { Women } \\
\text { having } \\
\text { subnoroups }\end{array}$ & $\begin{array}{l}\text { Women } \\
\text { not having } \\
\text { ubnorine } \\
\text { bleeding }\end{array}$ & $\begin{array}{l}\text { Total } \\
\text { uterine } \\
\text { bleeding }\end{array}$ & $\begin{array}{l}\text { P } \\
\text { value }\end{array}$ \\
$\begin{array}{l}\text { Vaginal } \\
\text { delivery }\end{array}$ & $3(7.3 \%)$ & $38(92.7 \%)$ & $41(100 \%)$ & 0.213 \\
$\begin{array}{lllll}\text { Caesarean } \\
\text { section }\end{array}$ & $9(18 \%)$ & $41(82 \%)$ & $50(100 \%)$ & \\
\hline
\end{tabular}

The incidence of pelvic infection was comparable in the vaginal delivery and caesarean section subgroup.

The incidence of pelvic infection was $4.9 \%$ in the vaginal delivery subgroup and $4 \%$ in the caesarean section subgroup (Table 6).

Table 6: Comparison of pelvic infection between PPIUCD subgroups.

\begin{tabular}{|c|c|c|c|c|}
\hline & \multicolumn{2}{|c|}{$\begin{array}{l}\text { Number of women in } \\
\text { PPIUCD subgroup }\end{array}$} & \multirow[t]{2}{*}{ Total } & \multirow{2}{*}{$\begin{array}{l}P \\
\text { value }\end{array}$} \\
\hline & $\begin{array}{l}\text { Vaginal } \\
\text { delivery }\end{array}$ & $\begin{array}{l}\text { Caesarean } \\
\text { section }\end{array}$ & & \\
\hline $\begin{array}{l}\text { Women } \\
\text { having pelvic } \\
\text { infection }\end{array}$ & $2(4.9 \%)$ & $2(4 \%)$ & $4(100 \%)$ & 1.000 \\
\hline
\end{tabular}

On follow-up of all the 41 women in postplacental IUCD vaginal delivery subgroup, on per speculum examination, $\mathrm{CuT}$ thread was not visible in 10 cases. Ultrasonography was done in all these 10 women. Out of these 10 cases, IUCD was seen in situ in 8 cases and in 2 cases, it was expelled. In the caesarean section subgroup, the thread of IUCD was not visible in 14 cases. Out of these 14 women, IUCD was not expelled in any of the case. This is shown below in Tables (Table 7 and 8).

Table 7: Thread visibility at 6 months in PPIUCD subgroups.

\begin{tabular}{|c|c|c|c|}
\hline \multirow{2}{*}{$\begin{array}{l}\text { Postplacental } \\
\text { IUCD } \\
\text { subgroup }\end{array}$} & \multicolumn{2}{|c|}{ Number of women } & \multirow[b]{2}{*}{ P value } \\
\hline & $\begin{array}{l}\text { Thread } \\
\text { not seen }\end{array}$ & Thread seen & \\
\hline $\begin{array}{l}\text { Vaginal } \\
\text { delivery }\end{array}$ & $10(24.4 \%)$ & $31(75.6 \%)$ & \multirow{2}{*}{0.698} \\
\hline $\begin{array}{l}\text { Caesarean } \\
\text { section }\end{array}$ & $14(28 \%)$ & $36(72 \%)$ & \\
\hline
\end{tabular}

Table 8: IUCD expulsion in PPIUCD subgroups.

\begin{tabular}{|llll|}
\hline $\begin{array}{l}\text { Postplacental } \\
\text { IUCD } \\
\text { subgroup }\end{array}$ & $\begin{array}{l}\text { Number of cases when } \\
\text { IUCD thread not visible }\end{array}$ & $\begin{array}{l}\text { P } \\
\text { IUCD } \\
\text { expelled } \\
\text { (complete } \\
\text { expulsion) }\end{array}$ & $\begin{array}{l}\text { IUCD not } \\
\text { expelled }\end{array}$ \\
& 2 & 8 & 0.163 \\
\hline $\begin{array}{l}\text { Vaginal } \\
\text { delivery }\end{array}$ & 0 & 14 & \\
\hline $\begin{array}{l}\text { Caesarean } \\
\text { section }\end{array}$ & & & \\
\hline
\end{tabular}

No woman in caesarean section subgroup had expulsion of IUCD whereas $9.8 \%$ women had expulsion of IUCD (either partial or complete) in the vaginal delivery postplacental IUCD subgroup. This difference was statistically significant, thereby proving that insertion of IUCD during caesarean section is a very effective method of contraception with zero expulsion rate (Table 9).

Table 9: Comparison of expulsion between PPIUCD subgroups.

\begin{tabular}{|c|c|c|c|c|}
\hline $\begin{array}{l}\text { Number of } \\
\text { women ( } \% \\
\text { within } \\
\text { group) in } \\
\text { postplacental } \\
\text { IUCD } \\
\text { subgroup }\end{array}$ & $\begin{array}{l}\text { IUCD } \\
\text { expelled } \\
\text { (complete } \\
\text { and } \\
\text { partial } \\
\text { expulsion) }\end{array}$ & $\begin{array}{l}\text { IUCD not } \\
\text { expelled }\end{array}$ & Total & $\begin{array}{l}\mathrm{P} \\
\text { value }\end{array}$ \\
\hline $\begin{array}{l}\text { Vaginal } \\
\text { delivery }\end{array}$ & $4(9.8 \%)$ & $37(90.2 \%)$ & $41(100 \%)$ & \multirow[t]{2}{*}{0.038} \\
\hline $\begin{array}{l}\text { Caesarean } \\
\text { section }\end{array}$ & $0(0 \%)$ & $50(100 \%)$ & $50(100 \%)$ & \\
\hline
\end{tabular}

10 out of 91 women in postplacental IUCD group and 12 out of 98 women in interval group got IUCD removed (Table 10). 
Table 10: IUCD removal.

\begin{tabular}{|llll|} 
& $\begin{array}{l}\text { Postplacental } \\
\text { IUCD }\end{array}$ & $\begin{array}{l}\text { Interval } \\
\text { IUCD }\end{array}$ & P \\
\hline $\begin{array}{l}\text { Women } \\
\text { who got }\end{array}$ & $10 / 91$ & $12 / 98$ & \\
$\begin{array}{l}\text { IUCD } \\
\text { removed }\end{array}$ & & & 0.788 \\
\hline
\end{tabular}

The women who got IUCD removed and did not get it reinserted were enquired about the cause of removal. The following graph shows the various causes of removal of IUCD in the two groups (Figure 1).

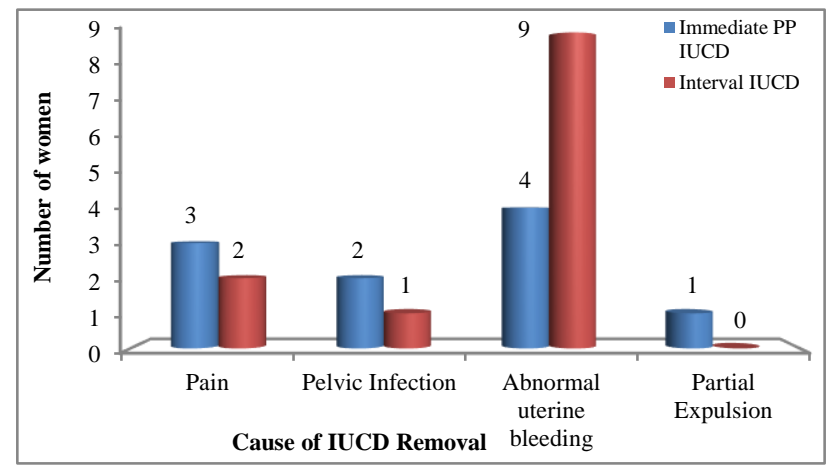

Figure 1: Cause of IUCD removal in PPIUCD and interval IUCD group.

\section{DISCUSSION}

The present study was designed to compare the complications following insertion of $\mathrm{CuT} 380 \mathrm{~A}$ in postplacental period with interval period insertions. The objective of the study was to compare in the two groups, the incidence of infection, menstrual abnormalities, expulsion or displacement of device.

Only $14.1 \%$ of the women agreed for postplacental IUCD insertion out of all the eligible women. The acceptance of IUCD in general is low in the society due to many misconceptions. A cross sectional study found that only $11.98 \%$ women accepted IUCD. ${ }^{3}$ In another study by Gujju et al, the acceptance level of postplacental IUCD was found to be $18.5 \% .{ }^{4}$ However, the acceptance of postplacental IUCD was much higher $(36 \%)$ in the study by Kanhere et al. ${ }^{5}$

After 6 months of follow-up, it was seen that in postplacental group, $4.4 \%$ of the women had expulsion of the IUCD whereas in the interval group, $4.1 \%$ of women had expulsion. In the study conducted by Lucksom et al, they reported nil expulsion rate in postplacental group versus $5.95 \%$ in the interval group. ${ }^{6}$ Another retrospective study showed that the expulsion rate was significantly lower in the interval insertion group $(2.7 \%)$ than in the immediate postpartum insertion group $(9.3 \%) .^{7}$ The number of women who had abnormal uterine bleeding was comparable within the two groups, with $13.2 \%$ women having abnormal uterine bleeding in the postplacental group and $13.3 \%$ women in the interval group. This incidence of abnormal uterine bleeding was higher as compared to other studies. In the study conducted by Eroglu et al, $2 \%$ of women had excessive menstrual bleeding in the postplacental IUCD group whereas $2.9 \%$ of the woman in the interval group had excessive bleeding. ${ }^{8}$ In our study, during the follow-up of 6 months, $4.4 \%$ of women had pelvic infection in postplacental IUCD group and $5.1 \%$ of women had pelvic infection in the interval group. This difference was statistically insignificant. Eroglu et al also reported that there was no statistically significant difference in the infection rates between the two groups. ${ }^{8}$

The mean pain score of the postplacental vaginal delivery group was calculated to be $0.17 \pm 0.704$ whereas that of the interval group was $0.22 \pm 0.925$. However this difference was not statistically significant. (value=0.739). In the study by Sharma et al, the incidence of pelvic pain was $13.54 \%$ in postplacental IUCD insertion group. ${ }^{9}$

The thread visibility at 6 months was $75.6 \%$ and $72 \%$ in the postplacental vaginal delivery and intra-caesarean group respectively. However, in the study by Halder et al, the thread visibility at 3 months was $91.3 \%$ in the post placental vaginal delivery group and $81.8 \%$ in the intracaesarean group. ${ }^{10}$

There was a statistically significant difference in the expulsion rates between the two postplacental IUCD subgroups. There was $9.8 \%$ expulsion rate in the postplacental IUCD vaginal delivery group whereas no case of expulsion in the intra-caesarean group. This observation is similar to the one observed by Muller et al in their study. They observed that after vaginal birth, the expulsion rate of IUCD was $50 \%$ whereas there was no case of expulsion of IUCD following intra-caesarean placement. ${ }^{11}$ Celen et al studied the clinical outcomes of the cesarean section patients receiving an IUCD. They found a cumulative expulsion rate of 17.6 per 100 women at the end of 12 months. ${ }^{12}$

In our study, $11 \%$ women in the postplacental group got IUCD removed whereas in the interval IUCD group, $12.2 \%$ women got IUCD removed, but the difference was statistically insignificant. The most common cause for IUCD removal was abnormal uterine bleeding in both the groups followed by pelvic pain. Ali et al found that across 14 countries they had studied during five-year period, $66 \%$ of IUCD episodes were still continuing at the time of the survey. ${ }^{13}$ The dominant reason for discontinuation was health concerns or side effects (15.7\%); $2.5 \%$ episodes were discontinued because of reported method failure, $5.9 \%$ due to a desire for a child and $3.5 \%$ because of no further need. Bangladeshi women showed the highest levels of discontinuation due to health concerns at $39.8 \%$ with Indonesia showing the lowest at $8.2 \%$. In another study by Akkuzu et al, the most common reason for discontinuation was partial 
expulsion in the postpartum group (52.6\%) and displacement in the interval group $(27.8 \%){ }^{14}$

\section{CONCLUSION}

After analysing the results in this study, the postplacental and interval IUCDs seem to be comparable for the incidence of infection and menstrual abnormalities. The expulsion rate for postplacental IUCD insertion after vaginal delivery and interval IUCD insertion also seems to be comparable. However, intra-caesarean PPIUCD insertion seems to have a much lower expulsion rate as compared to vaginal delivery PPIUCD insertion.

Postplacental IUCD seems to be as effective and safe as interval IUCD insertion. Moreover, it offers the advantage of postpartum contraception immediately following delivery.

\section{Funding: No funding sources}

Conflict of interest: None declared

Ethical approval: Not required

\section{REFERENCES}

1. Suri V. Post placental insertion of intrauterine contraceptive device. Indian J Med Res. 2012;136:370-1.

2. Pradhan S, Kshatri J, Sen R, Behera A, Tripathy R. Determinants of uptake of post-partum intra-uterine contraceptive device among women delivering in a tertiary hospital, Odisha, India. Int J Reprod Contracept Obstet Gynecol. 2017;6:2017-20.

3. Gadre S, Ahirwar R. Level of acceptance of IUCD insertion in Indian women - a cross-sectional mixed research from central India. Int $\mathbf{J}$ Reprod Contracept Obstet Gynecol. 2015;4:1079-85.

4. Gujju R, Prasad U, Prasad U. Study on the acceptance, complications and continuation rate of post-partum family planning using the post placental intrauterine contraceptive device among women delivering at a tertiary care hospital. Int J Reprod Contracept Obstet Gynecol. 2015;4:388-91.

5. Kanhere A, Pateriya P, Jain M. Acceptability and feasibility of immediate postpartum IUCD insertion in a tertiary care centre in Central India. Int J Reprod Contracept Obstet Gynecol. 2015;4:179-84.

6. Lucksom P, Kanungo B, Sebastian N, Mehrotra R, Pradhan D, Upadhya R. Comparative study of interval versus postpartum $\mathrm{Cu}-\mathrm{T}$ insertion in a central referral hospital of North East India. Int J Reprod Contracept Obstet Gynecol. 2015;4:47-51.

7. Thiery M, Van Kets H, Van der Pas H, van Os W, Dombrowicz N. The ML Cu250; clinical experience in Belgium and the Netherlands. $\mathrm{Br} \mathrm{J}$ Obstet Gynaecol. 1982;89:51-3.

8. Eroglu K, Akkuzu G, Vural G, Dilbaz B, Akin A, Taskin L, et al. Comparison of efficacy and complications of IUCD insertion in immediate postplacental/early postpartum period with interval period: 1year follow-up. Contracept. 2006;74:37681.

9. Sharma A, Gupta V, Bansal N, Sharma U, Tandon A. A prospective study of immediate postpartum intra uterine device insertion in a tertiary level hospital. Int J Res Med Sci. 2015;3:183-7.

10. Halder A, Sowmya M, Gayen A, Bhattacharya P, Mukherjee S, Datta S. A prospective Study to Evaluate Vaginal Insertion and Intra- Cesarean Insertion of Post-Partum Intrauterine Contraceptive Device. J Obstet Gynaecol Ind. 2016;66:35-41.

11. Muller A, Ramos J, Martins-Costa S, Dias R, Valerio E, Hammes L, et al. Transvaginal ultrasonographic assessment of the expulsion rate of intrauterine devices inserted in the immediate postpartum period: a pilot study. Contracep. 2005;72:192-5.

12. Celen S, Sucak A, Yildiz Y, Danisman N. Immediate postplacental insertion of an intrauterine contraceptive device during cesarean section. Contraception. 2011;84:240-3.

13. Ali M, Sadler R, Cleland J, Ngo T, Shah I. Longterm contraceptive protection, discontinuation and switching behaviour: intrauterine device (IUD) use dynamics in 14 developing countries. London: World Health Organization and Marie Stopes International; 2011.

14. Akkuzu G, Vural G, Eroglu K, Dilbaz B, Taskin L, Akin A, et al. Reasons for continuation or discontinuation of IUD in postplacental/early postpartum periods and postpuerperal/interval periods: One-year follow-up. Turkiye Klinikleri J Med Sci. 2009;29:353-60.

Cite this article as: Chauhan D, Gainder S. Comparison of clinical outcomes following CuT380A insertion in postplacental period with interval insertion. Int J Reprod Contracept Obstet Gynecol 2017;6:4111-5. 